\title{
BioMedicine
}

Volume 10 | Issue 3

Article 4

2020

\section{Effect of hydroalcoholic Allium atroviolaceum L. on the pathology of testicular tissue in cyclophosphamide-treated mice}

Follow this and additional works at: https://www.biomedicinej.com/biomedicine

Part of the Life Sciences Commons, and the Medical Sciences Commons

C) (i)

This work is licensed under a Creative Commons Attribution 4.0 License.

\section{Recommended Citation}

shahrani, mehrdad; asgharian, shirin; hosseini, alireza; bijad, elham; Anjomshoa, maryam; Rostamzadeh, ayoob; Asgharzadeh, najmeh; and lorigooini, zahra (2020) "Effect of hydroalcoholic Allium atroviolaceum L. on the pathology of testicular tissue in cyclophosphamide-treated mice," BioMedicine: Vol. 10 : Iss. 3 , Article 4.

DOI: 10.37796/2211-8039.1026

This Original Articles is brought to you for free and open access by BioMedicine. It has been accepted for inclusion in BioMedicine by an authorized editor of BioMedicine. 


\section{Effect of hydroalcoholic Allium atroviolaceum L. on the pathology of testicular tissue in cyclophosphamide-treated mice}

\section{Cover Page Footnote}

Funding This study was funded by the Research and Technology Deputy of Shahrekord University of Medical Sciences (grant number 2259). The funders had no role in study design, data collection and analysis, decision to publish, or preparation of the manuscript. Acknowledgements The authors gratefully thank the Research and Technology Deputy of Shahrekord University of Medical Sciences for all support provided. Conflict of interests The author(s) declare that they have no competing interests. 


\title{
Effect of hydroalcoholic Allium atroviolaceum L. on the pathology of testicular tissue in cyclophosphamide-treated mice
}

\author{
Mehrdad Shahrani ${ }^{a}$, Shirin Asgharian ${ }^{a}$, Alireza Hosseini ${ }^{\text {, }}$ Elham Bijad ${ }^{\text {, }}$ \\ Maryam Anjomshoa ${ }^{b}$, Ayoob Rostamzadeh ${ }^{\mathrm{c}}$, Najmeh Asgharzadeh ${ }^{\mathrm{a}}$, Zahra Lorigooini ${ }^{\mathrm{a}, *}$ \\ ${ }^{a}$ Medical Plants Research Center, Basic Health Sciences Institute, Shahrekord University of Medical Sciences, Shahrekord, Iran \\ ${ }^{\mathrm{b}}$ Department of Embryology and Histology, Faculty of Medicine, Shahrekord University of Medical Sciences, Shahrekord, Iran \\ ${ }^{c}$ Department of Anatomy and Neuroscience, Faculty of Medicine, Shahrekord University of Medical Sciences, Shahrekord, Iran
}

\begin{abstract}
Background: The most important side effects of Cyclophosphamide, as an anticancer broad-spectrum drug, are the negative effects on the reproduction and fertility because of oxidative stress. Considering the antioxidant properties of medicinal plants, especially those of the Allium genus, this paper studied the effect of hydroalcoholic extract of Allium atroviolaceum L. on the pathology of testicular tissue in CP-treated mice.

Methods: Groups of this experimental study consisted of normal saline recipients; three groups receiving A. atroviolaceum extract at 50, 100, $200 \mathrm{mg} / \mathrm{kg}$; three groups receiving A. atroviolaceum extract at 50, 100, and $200 \mathrm{mg} / \mathrm{g}$ and $6.6 \mathrm{mg} /$ $\mathrm{kg}$ of Cyclophosphamide; and a group given Cyclophosphamide at $1.6 \mathrm{mg} / \mathrm{kg}$. All injections were performed intraperitoneally. After 30 days, the testicular histological profile as well as the number of spermatozoa, the number of primary and round spermatocytes, and the number of spermatogonia were investigated.

Results: Cyclophosphamide treatment significantly reduced the lumen diameter, the seminiferous tubule diameter, the epithelial thickness, as well as decreased the quantity of spermatozoa and round and primary spermatocytes compared to the control group. Cyclophosphamide groups treated with A. atroviolaceum extract at 50,100 and $200 \mathrm{mg} / \mathrm{kg}$ in a significant manner improved these variables $(P<0.001)$.

Conclusion: A. atroviolaceum extract can significantly improve Cyclophosphamide-induced toxicity and pathological process on testicular tissue. It seems that this plant, with high antioxidant capacity, can be considered a complementary therapy for Cyclophosphamide to prevent undesirable effects on the reproductive system.
\end{abstract}

Keywords: Cyclophosphamide, Allium atroviolaceum, Pathology, Testicular tissue

\section{Background}

$\mathrm{T}$ he Allium genus plants belong to the Alliacea family. The genus Allium includes approximately 750 plant species [1]. These herbs are rich in flavonoids, saponins, sapogenins, and vaporizable sulfur compounds. These compounds control the characteristics of these plants, including their spicy smell and taste. These compounds are unstable and are easily converted to other compounds [2]. Moreover, the antioxidant effects of various species of this genus have also been proven [3-5]. Plants of this genus have been used as food in the culture of some countries for centuries, and also as preventive and therapeutic drug compounds [6, 7]. It has been shown that the plants of this genus are effective on cardiovascular disease, tumor growth, and aging process. It seems all of these diseases are associated with the effects of free radicals [8, 9]. Infertility involves $15 \%$ of couples all over the world. The factors of infertility in men are

Received 11 September 2019; accepted 3 December 2019.

Available online 1 September 2020.

* Corresponding author. Fax: +0098 3833330709.

E-mail address: zahralorigooini@gmail.com (Z. Lorigooini). 
responsible for about $40 \%-50 \%$ of all infertility cases [10]. The factors of male reason for infertility are obstruction, varicocele, infection, and exposure to toxins, rays, and certain drugs [11, 12]. Cyclophosphamide (CP) is one of these drugs that has been used extensively in recent decades [1315].

This drug, despite its extensive impact on various types of cancers has many adverse effects including reproductive toxicity[16]. It has been shown that oligospermia, azoospermia, as well as histological and biochemical changes are induced in testicular tissue and epididymis by CP[17, 18]. CP can lead to damage by degrading regenerative reactions in tissues and developing oxidative stress[16].

Due to these side effects, as well as the mechanism of their occurrence, complementary therapies, especially the usage of medical plants for the cure of different diseases, including infertility, have become widespread. Therefore, further studies are needed in this regard [19-22].

The usage of medical plants to increase fertility and also to cure certain conditions, such as hormonal imbalance, impotence (sexual weakness), oligospermia, sperm movement, prostate inflammation, and varicocele, have long been considered. On the other hand, the positive effect of certain plants of the Allium genus has already been studied on infertility.

A. cepa and A. sativum are among the species whose effect on fertility and the reproductive system has been shown[23, 24]. Black-violet Leek, botanically referred to as Allium atroviolaceum $\mathrm{L}$., is another species of the Alliaceae family and the Allium genus [25].

Considering the antioxidant effect of A. atroviolaceum, this investigation was carried out to examine the effect of this plant on the pathology of testicular tissue in CP-treated mice. This choice was due to its availability and the effects of this plant on improving men's fertility.

Due to the availability of this plant to the public usage, determining its effects on the reproductive system could lead studies to commercialize production.

\section{Methods}

\subsection{Plant material and Extraction}

Allium atroviolaceum, the wild leek with broadleaf, is a plant species endemic to Iran and widely used as a food source. The aerial part of early stage growing of $A$. atroviolaceum was gathered in the west of Iran from Sabzkooh mountain in May 2014 and then identified by a skilled botanist (Shirmardi Hamzeh Ali, PhD., Research Center of Agriculture and Natural Resources, P.O. Box 415, Shahrekord, Iran); a herbarium voucher (801) was assigned to the prepared plant specimen at the Medical Plants Research Center of Shahrekord University of Medical Sciences. Then, the plant was dehydrated by freeze dryer and ground by an electric mill. The extraction was carried out by maceration method with $70 \%$ ethanol. After $72 \mathrm{~h}$, the filtrated extract was concentrated with a rotary evaporator and then dehydrated in an incubator at $37^{\circ} \mathrm{C}$ [26].

\subsection{Animals}

64 male NMRI mice weighing 25-30 g and 7 weeks of age, were bought from the Tehran Razi Institute, and kept in the animal house of Shahrekord University of Medical Sciences under $\left(23 \pm 2{ }^{\circ} \mathrm{C}\right)$ and $12 /$ $12 \mathrm{~h}$ light/dark cycle. Animals had unlimited access to standard food and water. Before the experiments, the mice were allowed to acclimate to the environment for one week. The general health of the mice was monitored during the experiments. All steps of experimentation were done in accordance with the protocols of the University and the Guide for the Care and Use of Laboratory Animals of National Institutes of Health (Ethics code: IR.SKUMS.REC.1395, 193).

\subsection{Experimentation and measurement of variables}

In our experimental study, the animals were separated into 8 groups of 8 . Groups consisted of group 1: received $0.5 \mathrm{ml}$ of normal saline, group 2: received $6.1 \mathrm{mg} / \mathrm{kg}$ of $\mathrm{CP}$, groups 3-5: received 50 , 100 , and $200 \mathrm{mg} / \mathrm{kg}$ of $A$. atroviolaceum extract alone, respectively, treatment groups (6-8): received 50, 100 , and $200 \mathrm{mg} / \mathrm{kg}$ of A. atroviolaceum extract and $1.6 \mathrm{mg} / \mathrm{kg}$ of CP. All injections were performed intraperitoneally, once a day for 30 days [27]. Eventually, the mice were deep anesthetized using co-administration of ketamine $(60 \mathrm{mg} / \mathrm{kg}$, intraperitoneally) and xylazine ( $10 \mathrm{mg} / \mathrm{kg}$, intraperitoneally) $[28,29]$ and the testicles and epididymis were surgically removed to perform examinations of interest.

Testicles and epididymis were separated from each other and the right and left testicles were separately weighed and placed in $10 \%$ formalin and placed in paraffin. Sections $5 \mu$-thick were prepared and stained with haematoxylin and eosin (HE). The specimens were observed under an Olympus/3H light microscope. Then, seminiferous tubule diameter, lumen diameter, and epithelial thickness were 
determined at $100 \times$ magnification and the results were expressed in $\mu \mathrm{m}$. By examining seminiferous tubule, the spermatogonia count, primary and round spermatocytes, and spermatozoa number were determined by using optical microscope [24, 30]. To determine the index of right and left testicles, the weight of each testicle was divided by the body's weight. The index is expressed as a percentage [31].

\subsection{Statistical analysis}

Information was evaluated by one-way ANOVA and Tukey's test in Prism 5 software. To determine the correlation, Pearson correlation coefficient was used. $\mathrm{P}<0.05$ was considered as Significance level.

\section{Results}

\subsection{Influence of $A$. atroviolaceum extract on changes in lumen diameter}

One-way ANOVA analysis of results presented that there was a significant difference in lumen diameter between different groups $(\mathrm{P}<0.001)$. Tukey's post-test showed that the lumen diameter was significantly lower in the $\mathrm{CP}$ group than in the control group $(\mathrm{P}<0.001)$. The groups treated with $A$. atroviolaceum extract at 100 and $200 \mathrm{mg} / \mathrm{kg}$ had significantly greater lumen diameter than the control group $(P<0.001)$. Lumen diameter was significantly higher in the groups treated with $\mathrm{CP}$ with extract at 50,100, and $200 \mathrm{mg} / \mathrm{kg}$ than the group given $\mathrm{CP}$ alone $(P<0.001)($ Fig. 1$)$.

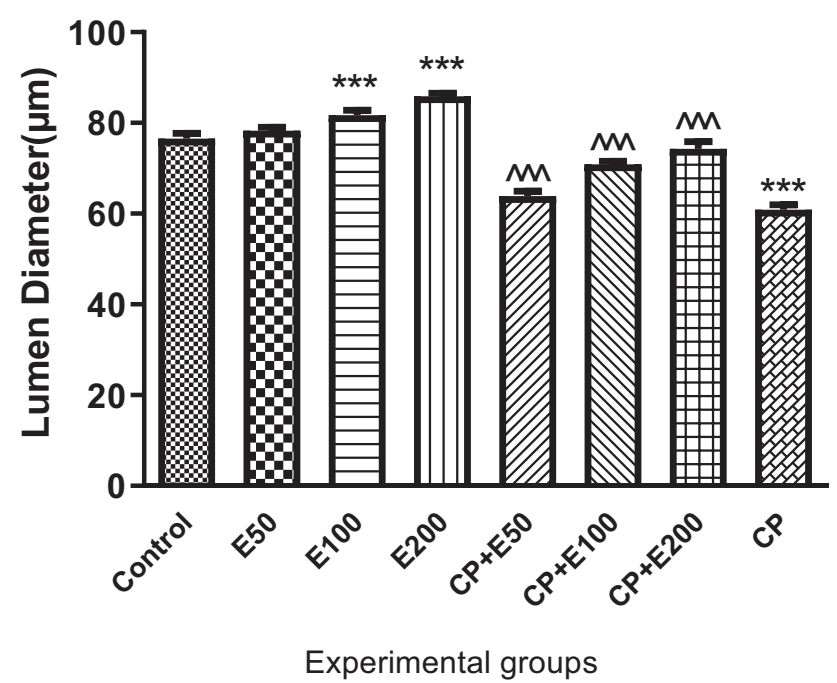

${ }^{* * *} \mathrm{P}<0.001$; compared with control group ${ }^{\wedge \wedge \wedge} \mathrm{P}<0.001$; compared with CP group

Fig. 1. Effect of Allium atroviolaceum L. extract (E) on lumen diameter in cyclophosphamide (CP)-treated mice.

\subsection{Influence of $A$. atroviolaceum extract on changes in testicular epithelial thickness}

One-way ANOVA analysis of results exposed a significant difference in epithelial thickness among different groups $(P<0.001)$. Results show that the epithelial thickness was significantly lower in the $\mathrm{CP}$-treated group than in the group receiving normal saline $(P<0.001)$. Epithelial thickness was significantly greater in the groups treated with $\mathrm{CP}+$ extract at 50, 100 and $200 \mathrm{mg} / \mathrm{kg}$ than the $\mathrm{CP}-$ treated group $(P<0.001)$. In the groups that received 100 and $200 \mathrm{mg} / \mathrm{kg}$ of the extract, a significantly higher epithelial thickness was observed than in the group receiving normal saline $(P<0.001)$ (Fig. 2$)$.

\subsection{Effect A. atroviolaceum extract on changes in seminiferous tubule diameter}

One-way ANOVA analysis of results illustrated that there was a significant difference in seminiferous tubule diameter among different groups $(P<0.001)$. According to Fig. 3 , Tukey's post-test showed that seminiferous tubule diameter was significantly different among different groups $(P<0.001)$. Seminiferous tubule diameter was significantly lower in the $\mathrm{CP}$ group than in the control group $(P<0.001)$. This variable was significantly higher in the treated groups with $\mathrm{CP}+$ extract at 50,100 and $200 \mathrm{mg} / \mathrm{kg}$ than in the $\mathrm{CP}$ group $(P<0.001)$. In the extract groups, seminiferous tubule diameter was significantly higher than in the control group $(P<0.001)$.

\subsection{Influence of A. atroviolaceum extract on changes in spermatozoa number}

According to Fig. 4, spermatozoa number was significantly lower in the $C P$ group than in the group receiving normal saline $(P<0.001)$. Tukey's post-test showed that spermatozoa number in the groups receiving $\mathrm{CP}+$ extract at 50, 100, and $200 \mathrm{mg} / \mathrm{kg}$ was significantly higher when compared to the CP group $(P<0.001)$. In the treated groups with extract at 100 and $200 \mathrm{mg} / \mathrm{kg}$, a significant higher number of spermatozoa was observed than in control group $(P<0.001)$.

\subsection{Influence of A. atroviolaceum extract on changes in primary spermatocyte number}

According to Fig. 5, primary spermatocyte number was lower in a significant manner in the CP group than in the group receiving normal saline $(P<0.001)$. Primary spermatocyte number in the 


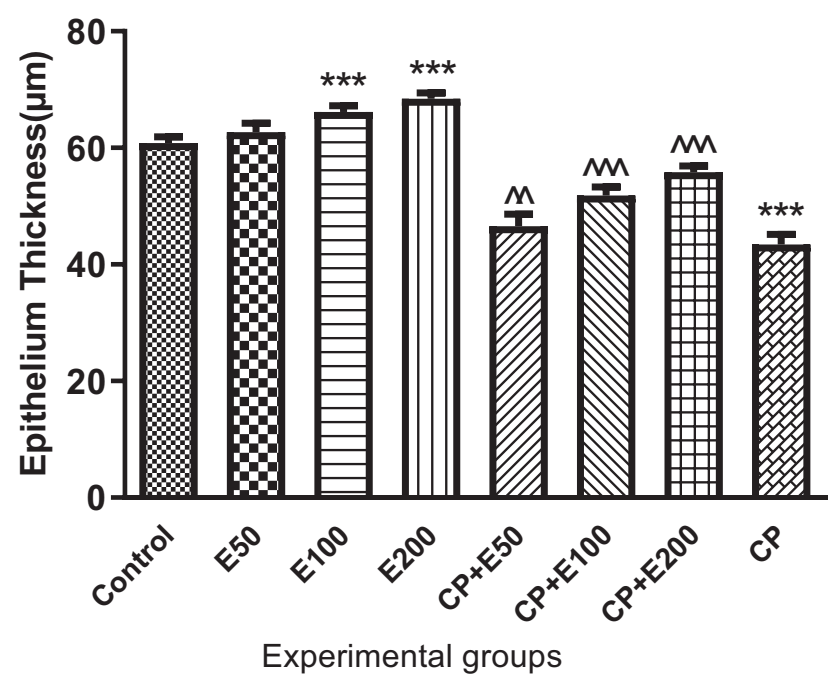

${ }^{* * *} \mathrm{P}<0.001$; compared with control group

${ }^{\wedge \wedge} \mathrm{P}<0.01$, ${ }^{\wedge \wedge \wedge} \mathrm{P}<0.001$; compared with CP group

Fig. 2. Effect of Allium atroviolaceum L. extract (E) on epithelial thickness in cyclophosphamide (CP)-treated mice.

groups receiving CP + extract at 100 and $200 \mathrm{mg} / \mathrm{kg}$ was significantly higher when compared to the $\mathrm{CP}$ group $(P<0.001)$.

\subsection{Influence of $A$. atroviolaceum extract on changes in round spermatocyte number}

In this study, there was a significant difference in the number of round spermatocytes in different

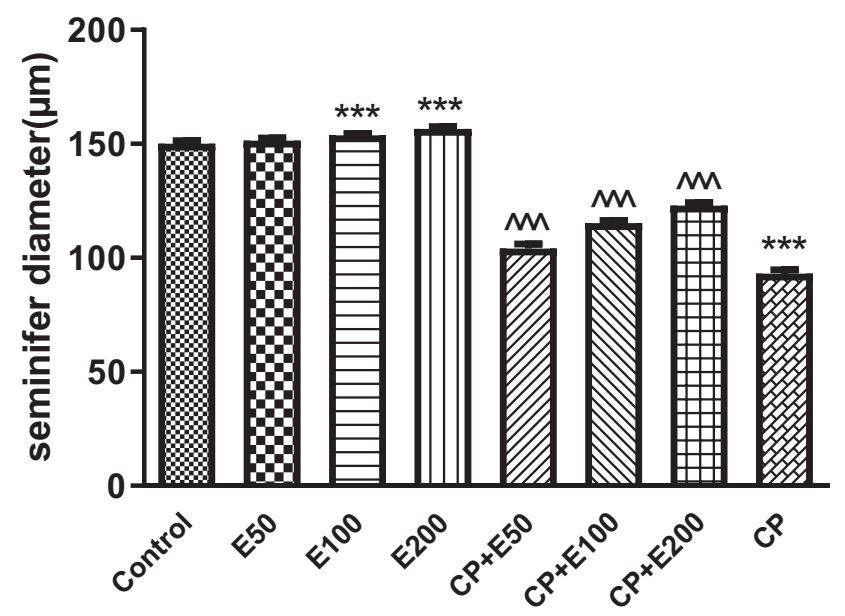

Experimental groups

$$
\begin{aligned}
& { }^{* * *} \mathrm{P}<0.001 \text {; compared with control group } \\
& { }^{\wedge \wedge} \mathrm{P}<0.001 \text {; compared with CP group }
\end{aligned}
$$

Fig. 3. Effect of Allium atroviolaceum L. extract (E) on seminiferous tubule diameter in cyclophosphamide (CP)-treated mice. groups $(P<0.001)$. Tukey's post-test exhibited that the number of round spermatocytes in the $\mathrm{CP}$ group was significantly lower when contrasted to the group receiving normal saline $(P<0.001)$. The number of round spermatocytes in the treated group receiving $\mathrm{CP}+$ extract at $50 \mathrm{mg} / \mathrm{kg}$ and also in the treated group with $\mathrm{CP}+$ extract at 100 and $200 \mathrm{mg} / \mathrm{kg}$ was significantly greater in contrast to the CP group ( $P<0.05$ and $P<0.001$, respectively). Additionally, round spermatocyte number in the groups receiving the extract at 50,100, and $200 \mathrm{mg} /$ $\mathrm{kg}$ was higher, significantly, compared to the CPtreated group $(P<0.001)$ (Fig. 6).

\subsection{Influence of A. atroviolaceum extract on changes in spermatogonia number}

As stated by the results of our study, the number of spermatogonia in the control and CP-treated groups and also extract groups and the groups receiving $\mathrm{CP}+$ extracts was not significant (Fig. 7).

\subsection{Influence of A. atroviolaceum extract on changes in right and left testicle index}

One-way ANOVA results showed that there was no significant difference in examined groups with respect to changes in right and left testicle index $(P<0.05)$. As stated by the results of our study, the changes in the right and left testicle index (Figs. 8 and 9, respectively) in the normal saline and CP groups and also the extract groups and the groups receiving $\mathrm{CP}+$ extracts at $\mathrm{mg} / \mathrm{kg}$ were not significantly different.

\section{Discussion}

$\mathrm{CP}$ is widely used to treat cancer malignancies. Despite its therapeutic effects, CP may lead to an extensive variety of side effects, such as reproductive disorders, in consumers. Usually the

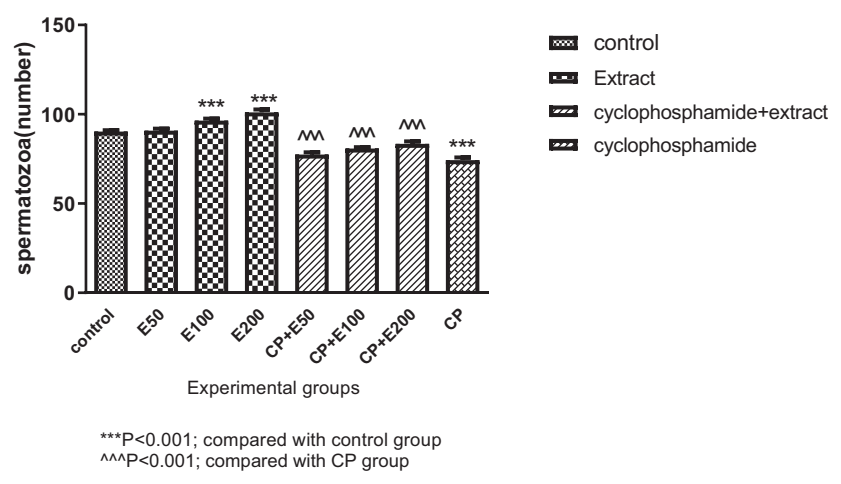

Fig. 4. Effect of Allium atroviolaceum L. extract (E) on spermatozoa number in cyclophosphamide (CP)-treated mice. 


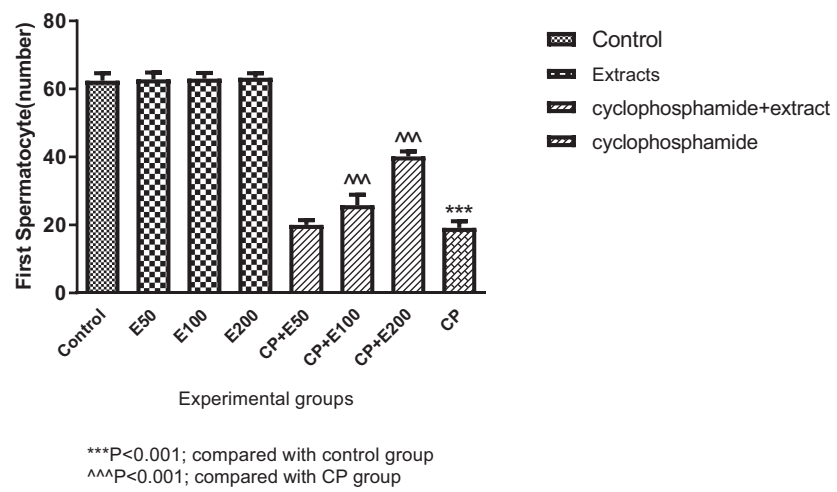

Fig. 5. Effect of Allium atroviolaceum L. extract (E) on primary spermatocyte number in cyclophosphamide $(C P)$-treated mice.

therapeutic effects of $\mathrm{CP}$ are limited due to the confirmed testicular toxicity in various animal species [32]. Anomalies caused by $\mathrm{CP}$ are due to excessive oxidative stress. Therefore, the administration of antioxidants during $\mathrm{CP}$ therapy is necessary to reduce oxidative stress and to detoxify tissues [33]. This research evaluated the influence of A. atroviolaceum on testicular tissue in CP-treated mice. In the present study, the testicular morphology, including lumen diameter, epithelial thickness, and tubular diameter, were considerably lower in the CP group than in the controls. Additionally, the number of spermatozoa, primary spermatocytes, round spermatocytes, and spermatogonia in the $\mathrm{CP}$ group were considerably lower than that in the controls. CP had no significant effect on body weight and right and left testicles in mice. In general, the outcomes of this study exhibited that CP had no significant effect on the body weight and right and left testicles. Cyclophosphamide reduced the number of spermatozoa, primary spermatocyte, round spermatocyte and spermatogonia, and decreased lumen diameter, epithelial thickness, and tubular diameter.

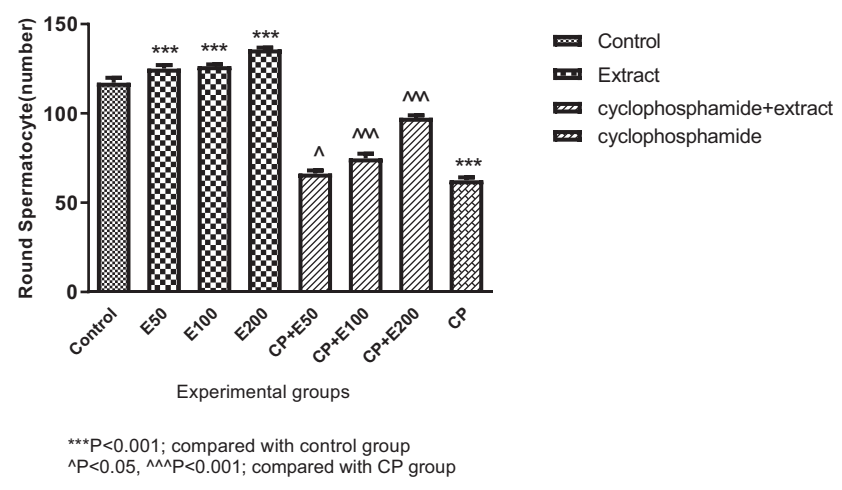

Fig. 6. Effect of Allium atroviolaceum L. extract (E) on round spermatocyte number in cyclophosphamide (CP)-treated mice.
In a study, CP treatment was associated with testicular tubule injury in mice, which is similar to the present research [32]. In the survey of Çeribaşi et al. (2010), CP treatment in mice was associated with a growth in the diameter of seminiferous tubules, a growth in germinal cell layer thickness, necrosis, damage and lack of maturity of germ cells, and testicular tissue atrophy, which is in agreement with the present review [34]. Another experimental study showed that the number of sperm cells, spermatids, and primary and secondary spermatocytes in the CP-exposed mice significantly decreased. In addition, CP caused atrophy of seminiferous tubules and decreased spermatogenic cells, which is similar to the outcomes of the present study [35].

In this research, $A$. atroviolaceum extract at 50, 100, and $200 \mathrm{mg} / \mathrm{kg}$ increased lumen diameter, epithelial thickness, tubular diameter, and spermatozoa and round spermatocyte number significantly contrasted with the controls. CP leads to reproductive toxicity by increasing the creation of reactive oxygen species, decreasing the glutathione content, and decreasing the activity of glutathione peroxidase [33, 36]. Glutathione peroxidase works as an antioxidant in protective spermatozoa in testicular and epididymal tissues and its decrease leads to infertility. This enzyme protects sperm against the free radicals by penetrating into the sperm plasma membrane, sperm nucleus, epididymal fluid, and epididymal region, and controls the evolution of the sperm [37, 38].

On the other hand, the ability of $\mathrm{CP}$ to produce free radicals, to peroxidize lipids, and to develop oxidative stress has been confirmed in rats [39, 40]. It has been stated that the administration of antioxidants along with CP reduces the toxicity of testicular tissue and the reproductive system significantly [33]. Oxidation-reduction balance is disrupted due to an increase in reactive oxygen species levels and free radicals and thus cellular activities, especially sperm

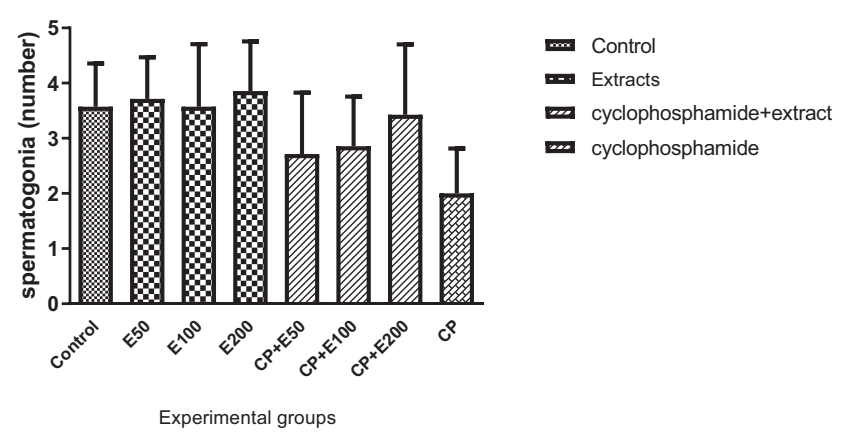

Fig. 7. Effect of Allium atroviolaceum L. extract (E) on spermatogonia number in cyclophosphamide (CP)-treated mice. 


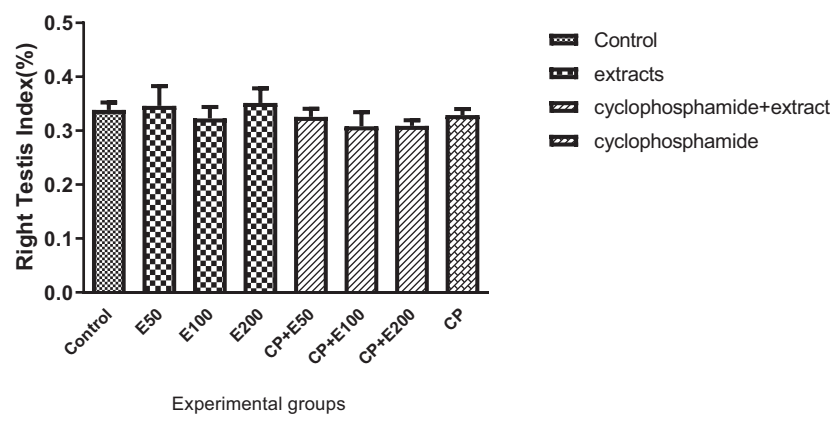

Fig. 8. Effect of Allium atroviolaceum L. extract (E) on changes in right testicle index in cyclophosphamide (CP)-treated mice.

production are disrupted as well. Antioxidants are scavengers that detoxify excessive ROS and have a serious role in maintaining oxidant and antioxidant balance in the body. [41, 42] Considering that the antioxidant activity of $A$. atroviolaceum extract has been confirmed in vitro and in vivo [43], it can be argued that the extract of this plant prevented damage to sex cells by decreasing the levels of free radicals and reactive oxygen species. A research managed by Nikravesh et al. (2010) to check the effect of $A$. cepa on testicular tissue in mice, showed that the extract of this plant increased spermatogenesis by influencing on the sperm ducts and cell proliferation in testicular tubules [44]. It has been argued that the presence of organic sulfur compounds in the plants of the Allium species significantly reduces the toxic influences of free radicals on the DNA of sperms by increasing glutathione levels and glutathione peroxidase activity. Organic sulfur compounds enhance the activity of antioxidant enzymes glutathione peroxidase and superoxide dismutase in different cells including hepatocytes, kidney cells, breast cells, and testicular cells, and protect cells via influencing peroxide and oxidative forms [45]. Flavonoids as major secondary metabolites in A. atroviolaceum are phenolic compounds which display a variety of biological

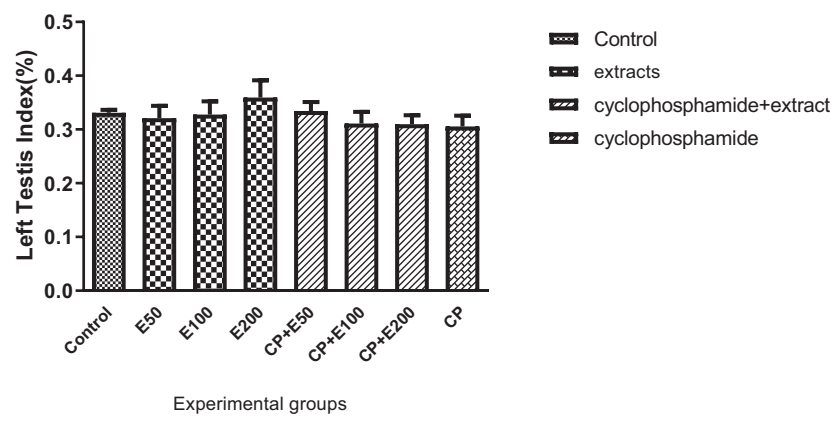

Fig. 9. Effect of Allium atroviolaceum L. extract (E) on changes in left testicle index in cyclophosphamide (CP)-treated mice. activities, such as antioxidant, anti-inflammatory, blood lipid-lowering and anticarcinogenic activities. In addition to possessing in vitro antioxidant activity, they may have beneficial effects on capillary permeability and blood flow [26]. They also exhibit anti-allergy and anti-inflammatory benefits from in vitro studies. Several studies have reported that antioxidants in diet can protect sperm DNA from free radicals and increase blood testis barrier stability [24, 46, 47]. So presence of sulfur and flavonoid compounds in A. atroviolaceum may exhibit protective effects on reproductive system in synergy.

\section{Conclusion}

Research confirmed the protective effect of $A$. atroviolaceum extract in contrast to testicular tissue damage in CP-treated male mice. Therefore, this plant can be used to prevent or reduce the harm caused by $\mathrm{CP}$ to the reproductive system in patients treated with this drug. Although the function of this extract still needs to be further investigated in human studies. Future studies can focus on the isolation of the main constituents affecting the reproductive system in this plant.

\section{Acknowledgments}

The financial support of the Deputy of Research and Technology of Shahrekord University of Medical Sciences is appreciated (Grant No: 2259). The authors of this study appreciate the Medical Plants Research Center Shahrekord, Iran and all participated in this study.

\section{Funding}

This study was funded by the Research and Technology Deputy of Shahrekord University of Medical Sciences (grant number 2259).

\section{References}

[1] Gordon JD, Speroff L, Speroff. Handbook for clinical gynecologic endocrinology and infertility. PA, USA: Lippincott Williams \& Wilkins Philadelphia; 2002.

[2] Jamshidi-Kia F, Lorigooini Z, Amini-Khoei H. Medicinal plants: Past history and future perspective. J HerbMed Pharmacol 2018;7(1):1-7.

[3] Bahmani M, Vakili-Saatloo N, Gholami-Ahangaran M, Karamati SA, Banihabib E, Hajigholizadeh G, et al. A comparison study on the anti-leech effects of onion (Allium cepa L) and ginger (Zingiber officinale) with levamisole and triclabendazole. J HerbMed Pharmacol 2013; 2(1):1-3.

[4] Ŝtajner D, Milić-DeMarino M, Canadanović-Brunet J. Screening for antioxidant properties of leeks, Allium sphaerocephalon L. J Herbs, Spices, Med Plants 2003;10(3): $75-82$. 
[5] Rafieian-kopaei M, Keshvari M, Asgary S, Salimi M, Heidarian H. Potential role of a nutraceutical spice (Allium hirtifolium) in reduction of atherosclerotic plaques. J HerbMed Pharmacol 2013;2(2):23-8.

[6] Fenwick GR, Hanley AB, Whitaker JR. The genus Allium-part 3. Crit Rev Food Sci Nutr 1985;23(1):1-73.

[7] Rajabzadeh A, Khaki AA, Khaki A. Antioxidant properties of Allium cepa (Onion) against permethrin-induced toxicity on LHCGR and SF1 genes in male rats. Crescent J Med Biol Sci 2018;5(4):327-31.

[8] Son EW, Sung-Ji Mo, Dong-Kwon Rhee, Suhkneung Pyo. Inhibition of ICAM-1 expression by garlic component, allicin, in gamma-irradiated human vascular endothelial cells via downregulation of the JNK signaling pathway. Int Immunopharmacol 2006;6(12):1788-95.

[9] Stajner D, Varga ISI. An evaluation of the antioxidant abilities of Allium species. Acta Biol Szeged 2003;47(1-4):103-6.

[10] Iammarrone E, Balet R, Lower AM, Gillott C, Grudzinskas JG. Male infertility. Best Pract Res Clin Obstet Gynaecol 2003;17(2):211-29.

[11] Hassun Filho PA, Cedenho AP, Lima SB, Ortiz V, Srougi M. Single nucleotide polymorphisms of the heat shock protein 90 gene in varicocele-associated infertility. Int Braz J Urol 2005;31(3):236-44.

[12] Organisation WH. WHO laboratory manual for the examination of human semen and sperm-cervical mucus interaction. Cambridge University Press; 1999.

[13] Fatima A, Khanam S, Jyoti S, Naz F, Rahul, Beg T, et al. Effect of tangeritin against cyclophosphamide-induced toxicity in the larvae of transgenic Drosophila melanogaster (hsp70-lac Z) Bg9. J Diet Suppl 2018;15(6):893-909.

[14] Shanafelt TD, Lin T, Geyer SM, Zent CS, Leung N, Kabat B, et al. Pentostatin, cyclophosphamide, and rituximab regimen in older patients with chronic lymphocytic leukemia. Canc 2007;109(11):2291-8.

[15] Young SD, Whissell M, Noble JCS, Cano PO, Lopez GP, Germond CJ. Phase II clinical trial results involving treatment with low-dose daily oral cyclophosphamide, weekly vinblastine, and rofecoxib in patients with advanced solid tumors. Clin Canc Res 2006:12(10):3092-8.

[16] Haque R, Bin-Hafeez B, Ahmad I, Parvez S, Pandey S, Raisuddin S. Protective effects of Emblica officinalis Gaertn. in cyclophosphamide-treated mice. Hum Exp Toxicol 2001; 20(12):643-50.

[17] Kirklandi RT, Bongiovanni M, Cornfeld D, McCormick JB, Parks JS, Tenore A. Gonadotropin responses to luteinizing releasing factor in boys treated with cyclophosphamide for nephrotic syndrome. J Pediatr 1976;89(6):941-4.

[18] Ghosh D, Das UB, Ghosh S, Mallick M, Debnath J. Testicular gametogenic and steroidogenic activities in cyclophosphamide treated rat: a correlative study with testicular oxidative stress. Drug Chem Toxicol 2002;25(3):281-92.

[19] Sedighi M, Bahmani M, Asgari S, Beyranvand F, Rafieiankopaei M. A review of plant-based compounds and medicinal plants effective on atherosclerosis. J Res Med Sci Off J Isfahan Univ Med Sci 2017;22:30.

[20] Moshfegh F, Baharara J, Namvar F, Zafar Balanejad S, Amini E, Jafarzadeh L. Effects of date palm pollen on fertility and development of reproductive system in female Balb/C mice. J Herb Med Pharmacol 2016;5(1):23-8.

[21] Bahmani M, Sarrafchi A, Shirzad H, Rafieian-kopaei M. Autism: Pathophysiology and promising herbal remedies. Curr Pharmaceut Des 2016;22(3):277-85.

[22] Mirazi N, Rezaei M, Mirhoseini M. Hypoglycemic effect of Satureja montanum L. hydroethanolic extract on diabetic rats. J Herb Med Pharmacol 2016;5(1):17-22.

[23] Hammami I, E1 May M. Impact of garlic feeding (Allium sativum) on male fertility. Andrologia 2013;45(4):217-24.

[24] Khaki A, Fathiazad F, Nouri M, Khaki AA, Khamenehi H, Hamadeh M. Evaluation of androgenic activity of allium cepa on spermatogenesis in the rat. Folia Morphol 2009;68(1): $45-51$.
[25] Lorigooini Z, Ayatollahi SA, Amidi S, Kobarfard F. Evaluation of anti-platelet aggregation effect of some Allium species. Iran J Pharm Res 2015;14(4):1225.

[26] Ghasemi S, Lorigooini Z, Wibowo JP, Amini-khoei H. Tricin isolated from Allium atroviolaceum potentiated the effect of docetaxel on PC3 cell proliferation: role of miR-21. Nat Prod Res 2019;33(12):1828-31.

[27] Hosseini A, Zare S, Ghaderi Pakdel F, Ahmadi A. Effects of vitamin $\mathrm{E}$ and Ginseng extract on fertility changes induced by cyclophosphamide in rats. J Reproduction Infertil 2010; 11(4):227-37.

[28] Ghazvini H, Shabani M, Asadi-Shekaari M, Khalifeh S, Esmaeilpour Kh, Khodamoradi M, et al. Estrogen and progesterone replacement therapy prevent methamphetamineInduced synaptic plasticity impairment in ovariectomized rats. Addiction Health 2016;8(3):145.

[29] Amiri S, Alijanpour S, Tirgar F, Haj-Mirzaian A, AminiKhoei H, Rahimi-Balaei M, et al. NMDA receptors are involved in the antidepressant-like effects of capsaicin following amphetamine withdrawal in male mice. Neuroscience 2016;329:122-33.

[30] Narayana K. An aminoglycoside antibiotic gentamycin induces oxidative stress, reduces antioxidant reserve and impairs spermatogenesis in rats. J Toxicol Sci 2008;33(1):85-96.

[31] Atawia RT, Mosli HH, Tadros MG, Khalifa AE, Mosli HA, Abdel-Naim AE. Modulatory effect of silymarin on inflammatory mediators in experimentally induced benign prostatic hyperplasia: emphasis on PTEN, HIF- $1 \alpha$, and NF- $\kappa$ B. N Schmied Arch Pharmacol 2014;387(12):1131-40.

[32] Elangovan N, Chiou TJ, Tzeng WF, Chu ST. Cyclophosphamide treatment causes impairment of sperm and its fertilizing ability in mice. Toxicology 2006;222(1):60-70.

[33] Ghalehkandi JG. Garlic (Allium sativum) juice protects from semen oxidative stress in male rats exposed to chromium chloride. Anim Reprod 2014;11(4):526-32.

[34] Ceribași AO, Türk G, Sönmez M, Sakin F, Ateșşahin A. Toxic effect of cyclophosphamide on sperm morphology, testicular histology and blood oxidant-antioxidant balance, and protective roles of lycopene and ellagic acid. Basic Clin Pharmacol Toxicol 2010;107(3):730-6.

[35] Tripathi D, Jena G. Astaxanthin inhibits cytotoxic and genotoxic effects of cyclophosphamide in mice germ cells. Toxicology 2008;248(2-3):96-103.

[36] Cai L, Hales BF, Robaire B. Induction of apoptosis in the germ cells of adult male rats after exposure to cyclophosphamide. Biol Reprod 1997;56(6):1490-7.

[37] Baradaran A, Rafieian-Kopaei M. Histopathological study of the combination of metformin and garlic juice for the attenuation of gentamicin renal toxicity in rats. J Ren Inj Prev 2013;2(1):15.

[38] Su D, Novoselov SV, Sun QA, Moustafa ME, Zhou Y, Oko R, et al. Mammalian selenoprotein thioredoxin-glutathione reductase roles in disulfide bond formation and sperm maturation. J Biol Chem 2005;280(28):26491-8.

[39] Nayyeri H, Latifimehr M. Impact of oxidative stress and onecarbon metabolism on male infertility; a mini-review to current trends. J Ischemia Tissue Repair 2017;1(1):26491-9.

[40] Nikravesh MR, Jalali M, Mohammadi S. Effects of crude onion extract on murine testis. J Reproduction Infertil 2010; 10(4):239-44.

[41] Sargazi Z, Nikravesh MR, Jalali M, Sadeghnia H, Rahimi Anbarkeh F, Mohammadzadeh L. Gender-related differences in sensitivity to diazinon in gonads of adult rats and the protective effect of vitamin E. IJWHR Sci 2015;3:40-7.

[42] Shokoohi M, Gholami Farashah MS, Khaki A, Khaki AA, Ouladsahebmadarek E, Aref Nezhad R. Protective effect of fumaria parviflora extract on oxidative stress and testis tissue damage in diabetic rats. Crescent J Med Biol Sci 2019;6(3): 355-60.

[43] Štajner D, Popović BM. Comparative study of antioxidant capacity in organs of different Allium species. Cent Eur J Biol 2009;4(2):224-8. 
[44] Rezvanfar M, Sadrkhanlou RA, Ahmadi A, Shojaei-Sadee H, Rezvanfar MA, Mohammadirad A, et al. Protection of cyclophosphamide-induced toxicity in reproductive tract histology, sperm characteristics, and DNA damage by an herbal source; evidence for role of free-radical toxic stress. Hum Exp Toxicol. 2008;27(12):901-10.

[45] Pedraza-Chaverrõ J, Maldonado PD, Medina-Campos ON, Olivares-Corichi IM, Granados-Silvestre MA, HernándezPando R, et al. Garlic ameliorates gentamicin nephrotoxicity: relation to antioxidant enzymes. Free Radic Biol Med 2000; 29(7):602-11.

[46] Yoshimura Y, Subedi H, Nishibori K. Impact of oxidative stress and supplementation with vitamins $\mathrm{E}$ and $\mathrm{C}$ on testes morphology in rats. J Reprod Dev 2006;52(2):203-9.

[47] Khaki A, Fathiazad F, Nouri M, khaki AA, ghanbari Z, ghanbari $\mathrm{M}$, et al. Anti-oxidative effects of citro flavonoids on spermatogenesis in rat. Afr J Pharm Pharmacol 2011;5(6): $721-5$. 